\title{
El imaginario moderno: \\ el mito del mercado pacificador
}

\section{Celso Sánchez Capdequí}

Universidad Pública de Navarra. Departamento de Sociología

\section{Resumen}

Este artículo considera el mercado como mito de la modernidad. Ésta representa al mercado como nueva moral laica de la humanidad y como victoria de la civilización sobre la naturaleza. La modernidad imagina el mercado como la base de una sociedad pacífica, no sólo como un modelo económico. Dinero, cálculo, previsión, método apuntan a un modelo universal de hombre cuyas acciones se basan en el autocontrol y en el dominio de las pasiones y emociones.

Palabras clave: mito, mercado, dinero, cálculo.

Abstract. The modern imaginary: the myth of pacifier market

This article considers the market to be a major myth. of modernity. This modernity represents the market as a new lay moral of mankind and as a symbol of the victory of civilization over nature. Modernity imagines the market as the basis of a peaceful society, and not a merely as an economic model. Money, calculation, foresight, meted; all this traits aim at an universal model of human being whose actions evolve around selfcontrol and mastery over passions and emotions.

Key words: myth, market, money, calculation.

\section{Sumario}

Significaciones sociales de la modernidad La hora del dinero

La nueva religión civil: el mercado

A menudo, los análisis sociales que enfrentan la tarea de estudiar las vicisitudes de la sociedad moderna acentúan la dimensión racionalizadora e instrumental en la que se trunca su inicial proyecto emancipador. Son comunes expresiones como el desencantamiento del mundo (Weber), la tragedia de la cultura (Simmel), el mundo administrado (Adorno), todas ellas referidas a una suerte de independización y autonomización de lo producido por el hombre moderno que, al cabo, termina dominándole y marcándole los ritmos de su propio comportamiento. El creador no se reconoce en una creación que se le 
escapa de sus manos siguiendo un ritmo imprevisible. La escisión entre el sujeto y el objeto, como bien sabía Simmel, parece insalvable, y más que autoexpresión lo que queda es zozobra, confusión e incertidumbre. La máquina, el dinero, el Estado, la ciencia, que nacen todos ellos a la luz de una modernidad con la que se inaugura la era de la mayoría de edad del hombre, se transforman en sistemas autopoiéticos y autorreferenciales (Luhmann), cuyos códigos y símbolos se aprestan a reducir la complejidad social (de la que ellos mismos son expresión) con un único objetivo: subsistir. Las rutinas y las repeticiones se apoderan, hasta naturalizarse, de una acción social carente de aliento humano. En este sentido, numerosos han sido los acercamientos sociológicos a la vida moderna que han acentuado, de manera estéril, el anquilosamiento de sus instituciones hispostasiándolo en esquemas epistemológicos (como el positivista, el estructuralista, el funcionalista, el sistémico) en los que tras el orden no se vislumbra la acción, tras la sociedad no se adivina el trato humano y tras las instituciones no existen otros protagonistas que los automatismos y las inercias reformulados como leyes y lógicas (de la historia, de la sociedad, de los códigos, de los sistemas). En el extremo, la modernidad parece ser una criatura que nació ya con parálisis, atenazada por la reglamentación burocrática y mercantil, en definitiva, que vino al mundo descreída y sin fe alguna que la alentase.

Sin embargo, a poco que se profundice en el alma de una sociedad moderna engreída de su tendencia secularizadora, se encuentra la fibra mítica que estimuló sus actos y que le hizo creer y, por ende, errar. El fracaso (si así pudiera denominarse) no es privativo de los actuales modelos de sociedad. Se trata de algo consubstancial a una realidad (de la que el hombre forma parte) en la que, como bien apunta el saber trágico, lo que hay es fractura ${ }^{1}$, falta ${ }^{2}$, herida ${ }^{3}$. La misma acción humana - continuando con el legado del pensamiento trágico- sólo y únicamente es posible porque esa falta que atraviesa la realidad del mundo y del hombre facilita la visita del daimon que se nos impone como necesidad y destino desatando nuestro actuar y, por lo mismo, encaminándolo fatalmente hacia el desatino. Como se recoge en el prólogo (en el cielo) del Fausto de Goethe, «el hombre yerra mientras tiene aspiraciones» ${ }^{4}$. En el pensamiento sociológico de Max Weber son frecuentes las referencias al daimon, que, desde el cuarto trastero de la conciencia humana, mueve los hilos de nuestras vidas sin saberlo. El punto de apoyo de Max Weber es, sin duda alguna, Goethe que, a lo largo del Fausto, apunta al pathos (mefistofélico) que mueve una acción humana que cursa sin saber de dónde procede y a dónde va, como recuerda la tragedia. Max Weber recoge esta imagen goetheiana, entre otras cosas, para hacer manifiesto el tenor ambivalente de la acción del empresario

1. Ortiz-Osés, A., Las claves simbólicas de nuestra cultura, Barcelona: Anthropos, 1993, cap. "El simbolismo radical», p. 55-71.

2. TRÍAS, A., La razón fronteriza, Barcelona: Destino, 1999, p. 74.

3. Lanceros, P., La herida trágica, Barcelona: Anthropos, 1997.

4. Goethe, J.W., Fausto, Madrid: Cátedra, p. 116, 1991. 
moderno movida por el espiritu (daimon) del capitalismo y su efecto final teñido de incertidumbre, zozobra y tedio con el que se cierra La ética protestante y el espiritu del capitalismo5.

En otras palabras, el momento de cosificación que pareció definir el entramado institucional y axiológico de la modernidad es el reverso (trágico) de haber anhelado, de haber confiado en un ideal, en definitiva, de haber(se) inventado como mito. Éste ha sido pasado por alto por el amaneramiento vano de un pensamiento sociológico muy apegado a la idea de orden/estructura y temeroso de trabar contacto con los procesos que despiertan la acción y que ponen de relieve la contingencia sobre la que se edifica cualquier organización humana. Es más, cualquier principio de estabilización (y de cosificación larvada) de la sociedad, como bien sabían Adorno y Horkheimer, hace pie en un olvido ${ }^{6}$, en concreto, el olvido de que ha sido creada, esto es, de que tuvo un principio (ocultado por el paso del tiempo) y posiblemente un fin.

Pues bien, tal vez nadie como Albert Hirschman ha transmitido la fe que alentó los primeros momentos de una sociedad que creía en el mito del comercio/mercado como mecanismo social pacificador de las conductas humanas. La Ilustración escocesa encarnó ese gesto mercantilista en el que el hombre europeo de la modernidad incipiente creyó ver el principio de la prosperidad humana y de la paz entre las diferentes culturas del mundo. La modernidad también cometió el error (trágico) de encantar la realidad, de intentar aglutinar en torno a una imagen los poderes irreconciliables que mueven el mundo. Como muy bien recuerda Hirschman (en el afán de explicar los orígenes de la cultura capitalista), el hombre moderno también creyó, y lo hizo con tal intensidad que, olvidándose de que era un acto de fe, lo hipostasió y lo universalizó integrando al conjunto vario de la cultura humana bajo su autoimagen racionalizadora y secularizadora.

El proceso de encantamiento que define la modernidad dibuja un horizonte ideal (el comercio) en el que comparece como imagen más emblemática el individuo propietario caracterizado por una acción orientada al intercambio económico, impregnada de disciplina, cálculo y austeridad y necesitada para su despliegue de instituciones especialmente significativas como el tiempo homogéneo, la ciudad, la técnica, el libre examen de la religión protestante y el dinero (entre otras). La propia condición de mito experimentado por la sociedad como horizonte de acción común y compartido explica que la expresión individuo propietario necesite, antes de nada, de un consenso social para que pueda emerger como ideal y para que puedan establecerse las condiciones políticas, económicas y morales que faciliten su realización en cada hombre. Por todo ello, si bien la manifestación de este mito siempre es, según Durkheim,

5. Sobre el particular, consultar El político y el cientifico, Madrid: Alianza, 1986; GOETHE, J.W., Fausto, Madrid: Cátedra, 1991; Poesía y verdad, Barcelona: Alba Editorial, 1999. También un texto valiosísimo sobre el influjo de la obra de Goethe sobre el pensamiento weberiano, GonZÁlez García, J.M., Las huellas de Fausto, Madrid: Tecnos, 1992.

6. Adorno, T.W.; Horkheimer, M., Dialéctica de la ilustración, Madrid: Trotta, 1994, p. 275. 
«individual por su objeto»" no por ello deja de ser el encantamiento de la sociedad su condición de posibilidad. El problema radica, como bien sabía el propio Durkheim, en que "es indudablemente de la sociedad de donde extrae todo lo que tiene de fuerza, pero no es a la sociedad a la que nos liga, es a nosotros mismos» ${ }^{8}$. El consenso de fondo de la modernidad comparece como el destino compartido por una época que insta a todo hombre (independientemente de su posición social, confesión religiosa, cultura y género) a realizarse como individuo propietario de su vida y de sus bienes, como ciudadano de una comunidad política (el Estado) a la que se adhiere libre y autónomamente a partir de decisiones que emanan de la soberanía de su conciencia.

Se trata de un tramo de la historia occidental en el que la idea de la muerte de Dios y, por ende, el desplome del dominio metafísico (desde el que las sociedades tradicionales gestionaban el devenir del mundo y de los hombres) da paso a un nuevo mito que concita todas las esperanzas de una sociedad que amanece, la modernidad. Ésta propone un nuevo icono, el hombre, y un nuevo escenario de interacción social, el mercado. Su narrativa simbólica aglutinadora sacraliza la idea de prosperidad del género humano derivado de la simpatía que, según Adam Smith, transforma las relaciones de mercado en principio catalizador del lazo social a escala universal. En concreto, la modernidad se concibe como «sociedad civil mercantil» ${ }^{9}$ en la que los encuentros sociales se orientan al intercambio de mercancías en virtud del cual los individuos, desde la más plena libertad y sin ninguna autoridad exterior a su conciencia (Iglesia, Estado, etc.), dan salida a su interés económico al tiempo que, colateralmente, el orden social se robustece. $\mathrm{El}$ aroma productivista y comercial va a impregnar una forma de ser y hacer basada en el convencimiento de que «la acción económica está por sí misma orientada hacia el bien, que posee un carácter moral que le es especial» ${ }^{10}$.

A pesar del nacimiento de una nueva fe colectiva, el hombre del momento, entronizado como un nuevo mesías, no ignora la fragilidad y la vulnerabilidad de sus obras (por oposición a la consistencia y solidez de las del Todopoderoso ya inexistente), manifestación de lo cual es la insidiosa presencia de las pasiones humanas (vanidad, ambición, envidia, etc.) en el trato social, que hace tambalear los ya de por sí débiles cimientos que sostienen el nuevo edificio social. La modernidad sabe que (a pesar de las continuas naturalizaciones en que desembocan los actos humanos) ha de librar batalla con lo otro del orden, la ambivalencia (la indeterminación, la contingencia, el caos) que, terca y tenaz, se opone a desaparecer, como muy bien recuerda Z. Bauman ${ }^{11}$. Es precisa-

7. Durkheim, E., La división del trabajo social, Madrid: Akal, 1987, p. 205.

8. Ibídem, p. 205.

9. SMith, A., La riqueza de las naciones, Madrid: Alianza Editorial, 1997, p. 55.

10. Dumont, L., Homo aequalis, Madrid: Taurus, 1982, p. 87.

11. Bauman, Z., Modernity and Ambivalence, Cambridge (Ingl.): Polity Press, 1991. Hay traducción española de las páginas 1-15, 53-74 de su versión original en Las consecuencias perversas de la modernidad, Barcelona: Anthropos, 1996, p. 73-119 (traducción de Celso Sánchez Capdequí). 
mente la constatación del caos religioso y político (la Guerra de los Treinta Años y la revocación del Edicto de Nantes) que rodea a la incipiente modernidad, como bien apunta Toulmin en su excelente Cosmopolis ${ }^{12}$, lo que crea las condiciones de un modelo social basado en la omnipotencia de un hombre que fía toda su suerte a la aplicación del método, el plan y el medio técnico para introducir previsión y orden en su entorno. De ahí el papel estelar que juegan en el quehacer del hombre moderno los medios como soportes técnicos que fascinan por evocar la seguridad ya perdida ante los imponderables de la existencia.

Este novedoso modelo de sociedad, cuya afinidad electiva con los promotores del pensamiento liberal representado por A. Smith, J. Locke, D. Hume y otros es incuestionable, cree en el gesto productivista del individuo propietario como mecanismo que armoniza el beneficio económico y la consolidación del orden. Si alguna pasión puede canalizar positivamente las tendencias perversas de las otras pasiones que anidan en el hombre, ésa es la de la búsqueda del enriquecimiento económico. Este argumento, que recoge muy bien Albert Hirschman en Las pasiones y los intereses, apunta al potencial salutífero que transmite al orden social el continuo intercambio de mercancías de unos individuos que, a pesar del culto que se les profesa en esta sociedad, se saben necesitados de lo que producen otros. Ya decía Adam Smith (expresando una creencia de la época) que sólo los pueblos y las culturas que han montado su estructura productiva sobre una eficiente división del trabajo tienen garantizados la prosperidad y el bienestar de sus miembros. Esta división del trabajo (cuyos efectos fueron tan denostados por Simmel) que se sustancia en la acción social en una "gran multiplicación de la producción de todos los diversos ofi$\operatorname{cios}^{13}$, desemboca en una situación que va a servir para poner de manifiesto en la modernidad algo consubstancial a la vida humana como es «la propensión a trocar, permutar y cambiar una cosa por otra ${ }^{14}$. De hecho, "cada trabajador cuenta con una gran cantidad de productos de su propio trabajo, por encima de lo que él mismo necesita; y como los demás trabajadores están exactamente en la misma situación, él puede intercambiar una abultada cantidad de sus bienes por una gran cantidad o, lo que es lo mismo, por el precio de una gran cantidad de bienes de los demás. Los provee abundantemente de lo que necesitan y ellos le suministran con amplitud lo que necesita él, y una plenitud general se difunde a través de los diferentes estratos de la sociedad ${ }^{15}$.

El nuevo modelo de sociedad que promueve la Ilustración escocesa sólo es comprensible desde la autonomía e irreductibilidad de los procesos sociales de intercambio económico. Si las sociedades tradicionales confieren prioridad a la división de funciones sobre los intercambios sociales, la modernidad modi-

12. Toulmin, S., Cosmopolis: The Hidden Agenda of Modernity, Chicago: The University of Chicago Press, 1990.

13. Smith, A., op. cit, 1997, p. 41.

14. Ibídem, p. 44.

15. Ibídem, p. 41. 
fica este escenario concediendo más importancia a éstos últimos. Esto constituye "una verdadera revolución copernicana en las ciencias sociales ${ }^{16}$ ", ya que la economía se libera de la cuestión de las necesidades, que desembocan en un modo de intercambio de suma cero «en el que las ganancias de unos eran realizadas a costa de los otros» ${ }^{17}$. No en vano, la sociedad tradicional se concibe como un organismo natural, global y estático, en cuyo interior las funciones están distribuidas desde el principio y donde predomina una economía basa$\mathrm{da}$, hasta entonces, en el disfrute de unos bienes limitados, centrada en una justa distribución de la riqueza (Aristóteles) que ofrece la naturaleza y, por ello, sujeta a un férreo control moral. Por el contrario, en la sociedad moderna el intercambio se libera de las rigideces religiosas y morales de antaño y, además, se desacopla de las cuestiones de distribución para abrirse a las de producción en el marco de un modelo de sociedad que se autoconstruye, sin otro referente que la dinámica de las prácticas humanas y apoyado en un tiempo ilimitado y abierto. Pieza clave de este proceso lo constituye el trabajo, toda vez que el nuevo modelo de hombre pasa de tener una actitud colaboradora con la naturaleza a «sustituirla por mecanismos o procesos artificialmente diseñados por el hombre» ${ }^{18}$. Se trata de una idea de trabajo que se ajusta a la nueva sensibilidad epocal en clara consonancia "con la creencia en las posibilidades ilimitadas del Homo faber sobre la que se apoyaba el nuevo antropocentrismo que sustituyó al antiguo orden religioso» ${ }^{19}$.

El corazón de la actividad económica ya no lo constituye la necesidad, sino la sed de enriquecimiento individual, lo cual abre las puertas, como sabían Veblen y Sombart, al consumo superfluo como acicate del sistema capitalista. En este sentido, el comercio, el intercambio económico y el mercado expanden su protagonismo universalizando un modo de vida dinámico, en perpetuo cambio simbolizado por la innovación técnica como la máquina de vapor y el ferrocarril, tendente a una diferenciación funcional cada vez más acentuada y abierto a un movimiento de emigración y colonización que implican la movilización de la propiedad y la aparición de nuevas necesidades por medio del establecimiento de relaciones a larga distancia. En este escenario urgen «medios móviles de cambio» ${ }^{20}$, como el dinero, que afluyen a los centros urbanos donde la omnipresente vida financiera que todo lo anega necesita un lenguaje universal, simple y preciso. Como bien sabía Simmel, la modernidad constituye el ejemplo más preclaro de una sociedad que lucha frontalmente contra la forma ${ }^{21}$, contra su quietud, en definitiva, contra el reposo de la vida dando pábulo a

16. Haesler, A.J., «Logique économique et determinisme social. Les parcours de la monnaie de l'echange chez G. Simmel», Bull de MAUSS, vol. 18, 1986, p. 112.

17. Naredo, J.M., "Configuración y crisis del mito del trabajo», Archipiélago, n. ${ }^{\circ} 48,2001$, septiembre-octubre, p. 18.

18. Ibídem, p. 18.

19. Ibídem, p. 18.

20. EliAS, N., El proceso de la civilización, México: FCE, 1993, p. 296.

21. Simmel, G., "El conflicto de la cultura moderna», REIS, n. ${ }^{\circ} 89$, enero-marzo, 2000, p. 316-330 (traducción de Celso Sánchez Capdequí). 
un modelo de sociedad en el que la economía del Homo faber creador y renovador de bienes y mercancías ejemplifica la sensibilidad de la época dada al dinamismo y al rápido envejecimiento de las cosas.

Es precisamente este trasiego permanente de las mercancías lo que permite hacer ver cierto atisbo de prosperidad y armonía en la sociedad y en la cultura humana en general. No en vano, el comercio entre individuos de una sociedad y entre culturas diferentes provoca necesariamente la autocontención emocional, el refinamiento en los gestos, la exquisitez en el trato, el respeto a la diferencia, el compromiso con lo pactado. Todos estos rasgos, además de favorecer la obtención de beneficio individual, fortalecen indeliberadamente el nomos cohesionador de la sociedad, apuntalan el orden de la convivencia entre los individuos.

De hecho, no conviene olvidar que, de las pasiones indoblegables que atraviesan la existencia humana, como recuerda Hirschman, la economía tiende a fortalecer la predicibilidad ${ }^{22}$ de la conducta individual, ya que se trata de la pasión menos voluble y azarosa, la más consistente. Por ello, el amor hacia el dinero que profesa el hombre moderno, en detrimento de otras pasiones, nutre la estabilidad de un orden colectivo en el que la actuación de los individuos es previsible, constante y transparente. Por tanto, la modernidad, en su estado inaugural, encuentra en la economía racionalidad, progreso y prosperidad. El mismo desarrollo técnico que tiene lugar en estos momentos con un gran influjo en la producción y en el transporte, el descubrimiento de América como un nuevo mercado, todo ello contribuye a un proceso de difusión mundial de la cosmovisión moderna sustentada en la idea de que el comercio acerca a las culturas, permite conocer e integrar lo diferente y, con ello, postular «el cosmopolitismo comercial que no es sólo un internacionalismo de las relaciones, sino el resurgir de una antigua aspiración, el hombre universal ("ya no hay desterrados, hay cosmopolitas"), cuyo agente social no podía ser otro que las nuevas y pujantes clases burguesas que promovían viajes científicos comerciales por todo el planeta» ${ }^{23}$.

Sin embargo, a la par que emerge este nuevo mito social, se produce una profunda metamorfosis que, acorde con los valores seculares que predominan en él, va a afectar en grado sumo a las formas de representación de lo real. La emergencia de la autoconciencia del hombre como artífice de su destino coincide con la conciencia (manifiesta o latente) de la transitoriedad de sus construcciones institucionales. La añoranza de una consistencia de la que el mundo y la sociedad empiezan a carecer se compensa con una proyección hacia el futuro al que se pretende controlar y predecir. Esta apuesta por anticiparse a los acontecimientos y privar al tiempo de sorpresas y desórdenes sólo es posible por el manejo de medios e instrumentos técnicos (ciencia, dinero, Estado) que estabilizan y uniformizan el curso de las cosas y hacen previsible lo que va a 
ocurrir. Se trata, sin duda alguna, de una lucha contra el tiempo. Precisamente la fe que anima al hombre moderno no le permite ver los obstáculos que en forma de riesgo y contingencia nacen de una infinidad de decisiones individuales, que, como muy bien nos recuerdan autores como N. Lumann, U. Beck y otros, colisionan entre sí en un contexto globalizado que funciona en tiempo real y cuyos efectos, siempre imprevisibles, cursan al margen de la idea de necesidad.

Básicamente, la función de los medios e instrumentos consiste en igualar lo desigual, en homogeneizar lo heterogéneo, en allanar el terreno quebrado. Se trata de reducir la complejidad, de avistar el futuro antes de que tenga lugar. Así, por ejemplo, el medio técnico dinero, tan esencial para este decorado social transido de pasión económica, facilita el cálculo sobre los (posibles) resultados futuros de operaciones económicas que han de decidirse en el presente. El medio técnico dinero no es sino la prolongación en el tiempo de la voluntad humana de, en algún sentido, remedar a Dios, no en vano, como éste, determina la in-determinación ${ }^{24}$ en una modernidad cargada de contingencia.

Esta omnipresencia de los medios y de los instrumentos funcionales, auténticos soportes de la acción del nuevo hombre, supone, sin embargo, una paulatina de-simbolización del mundo natural, el silenciamiento del lenguaje incorporado en los procesos naturales, el ocultamiento de las formas arquetípicas presentes en la materia. La relación hombre-entorno natural se modifica, ya que la sobrevaloración del yo en sus aspectos cognitivos deriva, de suyo, en una visión cosificadora de un entorno a su entera disposición. Si en las sociedades tradicionales de éste brotaban formas y figuras con las que, por semejanza, el hombre se autorrepresentaba el mundo con la ayuda de mitos, ahora, para ganar la batalla al tiempo y a la incertidumbre, debe homogeneizar su realidad exterior, despojándola de mensajes simbólicos e icónicos que, por su imprecisión semántica, no encajan en los moldes expresivos que empiezan a imponerse, los signos o medios técnicos con los que representar con pulcritud la realidad. Como recuerda Foucault, la forma del saber de las sociedades premodernas basadas en la semejanza y la similitud supone que «el mundo está cubierto de signos que es necesario descifrar y estos signos, que revelan la semejanza y afinidad, sólo son formas de la similitud. Así, pues, conocer es interpretar: pasar de la marca visible a lo que se dice a través de ella y que, sin ella, permanecería como palabra muda, adormecida entre las cosas» ${ }^{25}$. En este escenario, el vehículo de expresión es el símbolo que, por oposición al signo que surge en la modernidad con enorme pujanza, se caracteriza por acoger la connaturalidad entre el significante y el significado. De esta suerte, la fuerza está escrita sobre el cuerpo del león; la realeza, en la mirada del águila; la paz, en el vuelo de la paloma; la exuberancia de la naturaleza, en el rápido crecimiento del cerdo; la fecundidad, en la feminidad de la concha. La comprensión sim- 
bólica del mundo no puede, por tanto, atrapar y dominar la realidad, porque su interpretación no tiene fin, una imagen lleva a otra, un icono a otro por semejanza y similitud, pero sin encontrar un discurso absolutamente primero.

El nuevo cuadro epocal no anuncia la muerte del valor, sencillamente éste se transforma. Al desencantamiento del mundo propugnado por Weber le precede, ontológicamente y lógicamente, el encantamiento del yo propietario obsesionado por dominar a su antojo el devenir de lo real. Si bien se puede responder que el carácter calculador, la semiologización del mundo, la disciplina en la conducta, etc. son rasgos que pertenecen a un gesto humano enormemente racionalizado, no es menos cierto que le alimenta una pasión que se expresa velándose, es decir, de forma desapasionada. No en vano, es fe e ímpetu lo que mueve las acciones de unos hombres que, bajo la forma de individuo propietario, potencian un comportamiento económico como mecanismo armonizador de los intereses y garante de la convivencia ordenada entre los hombres y las culturas. Este argumento de la pasión moderna y de su forma austera de expresión, se verá con más nitidez en la explicitación de la religión protestante que predomina en este ambiente cultural.

Con el advenimiento de la modernidad, el hombre interrumpe la forma hermenéutica de conocimiento y la sustituye por la representación precisa de cuanto ocurre en el mundo exterior. La escisión entre las palabras y las cosas desemboca en la construcción de signos (conceptos, fórmulas científicas, formas monetarias) que, sin connaturalidad entre el significante y el significado, el pensamiento hace corresponder con algo que se encuentra entre los hechos del mundo. Su objetivo es ofrecer una pintura precisa de lo que rodea al hombre del momento. Cada signo se hermana unilateralmente con un objeto de la experiencia, de modo que el orden natural puede reflejarse correctamente en el pensamiento. Ajeno a las formas que se dibujaban en la materia de las que, por similitud, el hombre tradicional extraía estímulos para la acción, el pensamiento calculador organiza el mundo. Para ello se dota de los signos, es decir, de los medios e instrumentos que le permiten trabar contacto exitoso y eficiente con la espontaneidad del entorno. La obsesión del hombre moderno es el orden. Sobre este caldo de cultivo madura la hegemonía de los medios (como el dinero). Sólo desde él pudieron haber llegado a adquirir el protagonismo obtenido en los dos últimos siglos. El descrédito de la materia, la pretensión dominadora del hombre moderno, la expresión semiológica de la realidad, todo ello contribuye al nacimiento del gesto racionalizador de una cultura que, basándose en lenguajes técnicos dotados de precisión y univocidad, pretenden organizar la experiencia y alcanzar el futuro antes de que éste se produzca. Ya no es la semejanza la que une las palabras y las cosas, es la utilidad, de suerte que, por ejemplo, el soporte áureo de las monedas que acuñan los estados modernos ya no significa nada. Tan sólo sirve por su divisibilidad, durabilidad, transportabilidad, etc. para ejercer como soporte material de monedas de curso legal que llevan el cuño del Estado. No vale porque evoque la sagrada estabilidad del Ser, como en Grecia, sino porque es útil. Es más, el proceso de paulatina desimbolización del oro se acentúa en el momento que los 
estados ya no lo utilizan para sus monedas y lo sustituyen por otros metales (menos valiosos) como el cobre y, más tarde, por el papel moneda y el plástico. Estos soportes materiales del dinero representan oro, ya que, no en vano, abundan en mayor proporción, no significan nada, son más útiles en el manejo y en el transporte del dinero y, en definitiva, facilitan la realización de operaciones económicas a lo largo y ancho del mundo.

\section{Significaciones sociales de la modernidad}

Ya ha quedado dicho que el soporte cultural de esta sociedad civil mercantil (A. Smith) discrimina favorablemente y, por ello, sacraliza el valor de la inmanencia y lo secular, cuyos ejemplos más relevantes son el hombre, la acción económica y el escenario de la historia. El reencantamiento del mundo se traslada, como espacio liminar, al mercado, la fábrica, la bolsa desde donde el individuo da salida a su ansia ilimitada de beneficio y, de suyo, contribuye al fortalecimiento del orden colectivo. El simbolismo económico va extendiendo su tupida red hasta convertirse en el vehículo de expresión y de representación que va a dotar de unidad y coordinación a esta forma de ser y hacer social que no apunta a un más allá del mundo, sino a su propia inmanencia. En concreto, el hombre burgués aspira a convertirlo en previsible y homogéneo, a fabricarlo en los términos de $\mathrm{H}$. Arendt. No en vano, se trata de una cultura que mitifica lo sólido, como muy bien sabe Bauman, porque, precisamente, siente cercana la fragilidad de las cosas y la crecida de la ambivalencia.

En este sentido, puede hablarse, con Karl Polanyi, de «una verdadera fe que creía en la salvación del hombre aquí abajo gracias a un mercado autorregulador ${ }^{26}$. Con anterioridad, Walter Benjamin incide en el impulso religioso que anima la forma de vida capitalista en el sentido de que «el capitalismo sirve esencialmente a la satisfacción de las mismas preocupaciones, suplicios, inquietudes a las que daban respuesta antiguamente las llamadas religiones» ${ }^{27}$. Al abogar por este modelo laico de religión que no promueve un edén fuera del mundo, Benjamin va más allá de las tesis del propio Max Weber. No se limita a explicitar las condiciones religiosas que hacen posible el capitalismo, sino que ve en él una religión al subrayar la presencia de un ideal trascendente que lleva a actuar al hombre hacia un horizonte (inmanente) de salvación, como es el de la riqueza económica.

Iconos de esta modernidad economicista como el dinero, la mercancía, el trabajo, el maquinismo, la ciudad, el proletariado, el burgués, etc. no son sino condensaciones culturales de la nueva fe social. La realidad se dice en términos económicos. O como afirma Cornelius Castoriadis respecto del imaginario moderno, "esta significación económica es "monetizada" o convertida, por una parte, en una multitud de significaciones referidas a objetos concretos (los

26. PolanyI, K., La gran transformación, Madrid: La Piqueta, 1989, p. 223.

27. Benjamin, W., Gesammelte Schriften VI, Francfort del Meno: Suhrkamp, 1985, p. 100. 
bienes producidos, los instrumentos de producción, etc.) y, por otra parte, en una multiplicidad de multiplicaciones "abstractas", pero socialmente efectivas y activas (así, en la economía capitalista, capital, stock, trabajo, salarios, renta, beneficio, interés, son significaciones "abstractas", tematizadas y explicitadas como tales por y para los participantes y cuya explicitación es condición fáctica de la operación de esta economía)» ${ }^{28}$.

El propio marchamo productivista y utilitarista de esta forma social tiende a ensombrecer la dimensión cultura $^{29}$ que la sitúa en el mundo y con cuyo esclarecimiento se relativiza la idea promovida y difundida desde ella misma de que la necesidad material se constituye como la necesidad de las necesidades, la necesidad universal del hombre. Sin embargo, esta propia definición es imaginaria en el sentido que da al término Castoriadis, esto es, imaginada e inventada socialmente. O, como añade Marshall Sahlins, «la producción, en consecuencia, es algo más que una lógica práctica de la eficacia material y algo distinto de ella. Es una intención cultural. El proceso material de la existencia física es organizado como un proceso significativo de ser social, que representa para los hombres, puesto que siempre están definidos culturalmente en determinadas formas, su único modo de existencia ${ }^{30}$.

El substrato imaginario de la sociedad moderna contiene diferentes condensaciones simbólicas que guardan entre ellas una afinidad electiva por coparticipar de un mismo gesto cultural. Todas ellas son momentos que expresan el fondo cultural unitario del mito del mercado. Cada una de ellas y la adecuación entre las mismas carece de sentido fuera de este marco simbólico. Comprender, por ello, lo económico en la modernidad al margen del nutriente cultural y mítico que lo desata y que lo sitúa en el mundo es el primer paso para malinterpretar la realidad social reduciendo lo histórico a lo a-histórico, la variedad a la unidad y la cultura a la naturaleza.

Una de las significaciones culturales de este escenario social, tal vez la más emblemática, es la del individuo propietario, que encarna la deificación del hombre y su omnipotencia técnica. Esta figura cobra especial protagonismo bajo la forma de sujeto que se sujeta a si mismo en lo tocante a decisiones políticas y cognitivas. En las primeras el yo decide desde la soledad de su conciencia, como garante de su libertad, la adhesión (o no) voluntaria a una comunidad política (el Estado) en la que el primado de la ley ha de velar por su vida y sus bienes. En las segundas, el yo hace de su conciencia el eje indubitable del cual hacer derivar con garantías cualquier proceso cognitivo orientado a desescombrar las leyes que rigen el devenir del mundo. El yo, por tanto, adquiere máxima relevancia simbólica hasta el punto que, como dice Durkheim, caracteriza a una modernidad que, por el culto que rinde al individuo, difícilmente puede autopercibirse como sociedad.

28. Castoriadis, C., La institución imaginaria de la sociedad II, Barcelona: Tusquets, 1989, p. 317.

29. Alexander, J.A., Sociología cultural, Barcelona: Anthropos, 2000.

30. Sahlins, M., Culture and Practical Reason, Chicago: The University of Chicago Press, 1976, p. 169. La cursiva es mía. 
Esta figura central en la vida moderna comparece con el rasgo de autosuficiencia que le aporta el hecho de ocupar el lugar de Dios en el escenario de la historia. Su gesto austero, severo e inexpresivo alude a la tensión ilimitada de un hombre que deposita sus esperanzas salvíficas en la edificación de un carácter diferenciado, de una identidad. El yo, libre de las cadenas del pasado, se convierte en artífice de su propia biografía gestando día a día una obra, una empresa en la que busca inmortalizarse. La esfera económica, como dice Veblen ${ }^{31}$, constituye el escenario de esa búsqueda pacífica de reconocimiento y distinción que antaño se libraba en el desafío y en la competencia bélica entre los hombres. No en vano, en esta época proliferan en el mundo del arte los retra$\operatorname{tos}^{32}$, en los que se pretende singularizar e inmortalizar a los prohombres de la sociedad que se han hecho a sí mismos a lo largo de su vida sin otros instrumentos que su pericia y su constancia. En este sentido, puede recordarse el retrato del matrimonio Arnolfini realizado por Jan van Eyck como expresión de que «no existe en esta época nada más profundo que esa aventura personal de ser uno mismo por encima de las propias circunstancias» ${ }^{33}$.

La vida económica se presta a esta obsesión del individuo por engrosar la lista de las celebridades de la sociedad, porque en ella de nada vale lo azaroso de precedentes familiares, culturales y sociales, y lo que brilla con luz propia es la autorrealización individual, la forja de un carácter. De modo que en esta actividad en la que la gestión atinada del futuro es nuclear, sólo el sistema, el plan, el cálculo, la abnegación, la austeridad facilitan el reconocimiento como llave de entrada en el Olimpo de la memoria colectiva. Esta descripción encaja con la que comúnmente se ha difundido del burgués (Sombart), del usurero (Marx), del capitalista (Weber). En estas estampas de época el individuo, que hace del beneficio económico su vida, parece no dejar nada sin atar, aleja la sorpresa, acalla su espontaneidad, lleva el control de su gestión y de su vida hasta límites insospechados, da muestras de una enorme desconfianza ante el resto de la sociedad hasta poner en peligro los vínculos de solidaridad con los otros, todo lo cual preludia la jaula de hierro en que se convierte una forma de vida que acaba desencantándose ${ }^{34}$.

Sin embargo, si bien esto es verdad, también lo es, a pesar de haberse olvidado, que una esperanza se apoderó de la sociedad moderna en sus primeras

31. Veblen, T., Teoría de la clase ociosa, México: FCE, 1974, p. 35.

32. Consultar el trabajo A Cultural History of Gesture (Bremmer, J.; Roodenburg, H., eds.), Nueva York: Ithaca, 1991.

33. RuIZ-DOMÉNEC, J. E., Observando la modernidad desde la Edad Media, Valencia: Institución Alfonso el Magnánimo, 1999, p. 33.

34. En cualquier caso, identificar unilateralmente la conciencia moderna con la racionalidad medios-fines es un error, ya que ésta constituye el resultado fatal de un modelo de acción que, a fuerza de cuantificar y prever, se hace uno con el cálculo. En la conciencia (según el mito del comercio pacificador) anida la soberanía del individuo que decide desde sí y que da cuenta ante los demás de sus decisiones, alimentando con ello un espacio público que quiebra en la posmodernidad por la hegemonía de las mónadas privadas que navegan por la red virtual sin control político de ningún tipo. 
fases, al creer en la dimensión salutífera del comercio como mecanismo de armonización de lo público y lo privado. Esta esperanza era sentida por los individuos que apostaron por la pasión económica como garante de prosperidad, progreso y paz. Por tanto, éstos, que a menudo las reflexiones sociológicas los caracterizan como seres desalmados y maquínicos, no carecían de pasión, sino que se manifestaba como una actividad, lo económico, en la que obraba y operaba ocultándose en la severidad y el ascetismo organizador y regulador. Sin aspavientos de cara a la galería y con una austeridad sólo comprensible por el influjo del dogma protestante, la pasión que mueve sus vidas se expresa en el convencimiento inquebrantable y en el carácter férreo con que libran la batalla contra el tiempo (futuro) en busca de enriquecimiento y posteridad. De algún modo, se puede decir que el individuo propietario no es ajeno al impulso religioso con el que aspira a trascenderse en el escenario histórico dejando señal de buen hacer, tesón, carácter. Consciente o inconscientemente, el hombre burgués pretende perdurar en el tiempo, convertirse en paradigma y modelo de acción a través de la obra legada a su ciudad. En una sociedad como la moderna, ajena a cualquier forma de huida metafísica del mundo, pervive el anhelo de inmortalidad. No en vano, se idolatra, al decir de Bauman, «a todas aquellas personas cuya presencia en el mundo "establecía una diferencia" y, por ello, hacía historia» ${ }^{35}$.

Otro de los elementos que forma parte del todo cultural sobre el que se edifica la forma de la vida moderna es el de la religión protestante, de gran implantación en la Europa anglosajona en esta época. Se trata de un credo religioso que, cuando menos, en una de sus etapas ${ }^{36}$, potencia sobremanera las facultades racionalizadoras y sistematizadoras del fiel impregnando de ascetismo y autocontrol a su conducta. En una de sus sectas, el calvinismo, Weber cree ver ciertas condiciones de espiritualidad religiosa que explicarían la tenacidad del fiel en trabajar y producir con ahínco para, por un lado, ahuyentar la duda y, por otro, obtener el reconocimiento público de su buen hacer, lo cual redunda en una mayor autoconfianza individual. Ambos hechos son respuesta a las dudas que circundan la vida del calvinista, toda vez que ignora la determinación de Dios acerca de su salvación. La distancia entre su reino y lo mundano es tal que, a falta de conocer su veredicto definitivo, sólo cabe estar atento a ciertas señales que pudiera enviarle. El autoconvencimiento que se deriva del trabajo denodado, del autocontrol afectivo, de la austeridad en el gasto, del alejamiento de todo regodeo orgiástico en el placer y de la prohibición del con-

35. Bauman, Z., La sociedad individualizada, Madrid: Cátedra, 2001, p. 271.

36. En su excelente libro The Romantic Ethic and the Spirit of Modern Consumerism (Oxford: Basil Blackwell, 1987), Colin Campbell subraya que las derivaciones que del calvinismo efectúa Weber para, desde él, explicar el posible surgimiento del capitalismo, pudieran ser muy otras, si en vez de estudiar el protestantismo hasta el siglo XVII, que fue el período que investigó Weber, hubiese optado por analizar sectas protestantes de fines del siglo XVIII en adelante, como el metodismo, que proyectan una imagen muy distinta de Dios, toda vez que su presencia puede constatarse en un terreno prohibido para la secta calvinista, como es el de los sentimientos y las emociones de los hombres. 
sumo fútil y de la contemplación de las imágenes es traducido por el individuo como mensaje favorable del Todopoderoso, no en vano, como dice Weber con respecto al Dios calvinista, "Dios ayuda al que se ayuda a sí mismo»" Todos estos momentos constituyen una forma de hacer del fiel que busca señales relativas al veredicto divino sobre su salvación en lo mundano, en el trabajo, en la disciplina, en el éxito profesional, en las «buenas obras» realizadas in Majorem Dei Gloriam. Sin lugar a dudas, se percibe cierta sintonía semántica entre la acción del individuo propietario y la llamada espiritual que tira de la acción del fiel calvinista, toda vez que en ambos sólo cabe actuar desde la tenacidad, el ascetismo y el plan. Se trata de una afinidad electiva que se produce en una época en la que se sacraliza el hacerse a sí mismo del individuo, el obrar su propia identidad.

En cualquier caso, es oportuno subrayar cómo en muchas de las páginas de Weber aparecen descripciones del carácter calvinista en las que aflora una enorme emoción. Se podría hablar, con Colin Campbell, «de intensa pasión, pero controlada ${ }^{38}$. Con ello se trataría de subrayar que el prototipo de fiel calvinista austero, abnegado y calculador tan sólo apunta a una parte de la realidad, ya que la intensidad con la que vivía la duda, la búsqueda permanente de señal divina, la soledad con la que afrontaba la tarea diaria de no dejarse llevar por la tentación son elementos que ponen de manifiesto que «estos individuos experimentaban emociones religiosas más intensas que las de los fieles de otros dogmas» ${ }^{39}$. Por ello, se constata que en el fondo del espíritu moderno fluye la pasión que, paradójicamente, se manifiesta en un obrar desapasionado, sistemático y ascético.

Otra de las instituciones más representativas de la modernidad es la división del trabajo. Como ya apuntara Durkheim, tras ella late el supuesto de que una sociedad que fragmenta funcionalmente su estructura en subsistemas (ciencia, arte, religión, etc.) con el fin de resolver más eficientemente los problemas derivados de su elevada complejidad, obliga a los mismos a interactuar y entenderse permanentemente con el entorno, es decir, con el resto de subsistemas. Sin embargo, cada subsistema lo hace a partir de unos medios simbólicos de comunicación (el dinero en el subsistema económico, el poder en el político, la belleza en el arte, la verdad en la ciencia) únicamente en nombre un determinado dominio funcional y sólo en nombre de él. De esta suerte, autores como Marx, Simmel y Weber detectaron a principios de siglo el peligro de la especialización, la falta de amplitud en el horizonte de acción del hombre moderno, la supremacía de la función sobre la expresividad individual, de lo objetivo sobre lo subjetivo. Más recientemente, Habermas ha incidido en este aspecto subrayando la pérdida del potencial argumentativo del lenguaje humano, toda vez que, en aras de una mejor gestión de la complejidad que pretenden controlar, los

37. Weber, M., La ética protestante y el espiritu del capitalismo, Barcelona: Península, 1987, p. 145 .

38. Campbell, C., op cit., 1987, p. 218.

39. Ibídem, p. 123. 
subsistemas manejan sólo dos valores simbólicos (tener/no-tener en el económico, justo/injusto en el jurídico, verdad/falsedad en el científico). Se trata de subrayar que "la división moderna del trabajo aumenta el número de dependencias en la misma medida que hace desaparecer a las personalidades detrás de las funciones» ${ }^{40}$. Los individuos ajustan sus comportamientos a las reglamentaciones formales propias de cada función socialmente necesaria, la cual priva a los mismos, como bien sabía Marx, de autoexpresarse en lo que hacen. Su acción funcional es exterior a sus necesidades internas, desconectando, así, obra y motivación en el marco de interacciones objetivadas.

$\mathrm{Al}$ predominio de lo funcional también contribuye el hecho de que la moderna división del trabajo se ve facilitada por el dinero monetario, en la medida en que éste aporta un lenguaje universal, homogéneo y preciso para el intercambio de las unidades producidas por los individuos en nombre de los diferentes subsistemas funcionales. Simmel constata la implicación de la economía monetaria con el proceso de la división del trabajo, toda vez que «el dinero hace mutuamente intercambiables a todos sus elementos e instituye una relación de dependencia y prolongación recíprocas de todos los impulsos. Por otro lado, el dinero se puede comparar con la sangre, cuya circulación continuada penetra en todas las ramificaciones de los miembros y alimentando a todos por igual, garantiza la unidad de sus funciones» ${ }^{41}$. En este aspecto, las producciones humanas se homologan entre sí a partir del medio dinero ignorando cualquier otro valor que no se ajuste a lo cuantitativo. Las mercancías hablan un mismo lenguaje independientemente de su contexto de gestación, de la identidad de sus artífices, del esfuerzo necesario para su producción, etc. Lo más propiamente humano, lo cualitativo y lo singular, tiende a perder protagonismo en la modernidad en un sistema de producción que, como bien sabía Simmel, por un lado, hace que las muchas almas que intervienen en cada producto priven a éste de sello personal y, por otro lado, al orientar la producción al consumo masivo, produce para el hombre medio, para un ente fantasmal en el que tienen cabida el mayor número de personas posible.

Por otra parte, la cosmovisión moderna reinventa el concepto de tiempo, que, impregnado de resabios judeocristianos ${ }^{42}$, se despliega en el escenario de la historia. Este es el medio en el que se expresa la modernidad, a diferencia de las sociedades tradicionales que apuntalaban su estructura y orden a partir de una legitimación de carácter trascendente situada fuera de la historia. En la nueva sociedad la historia se despoja de cualquier vestigio ultraterreno, pero no por ello prescinde de un sentido que orienta su devenir. El perfil escatológico de este tiempo imaginario es evidente en conceptos tales como evolución, progreso, desarrollo, crecimiento, todos ellos transidos de un telos que, bajo diferentes expresiones como la autoconciencia del espiritu (Hegel), la benevolencia del mercado (A. Smith), el desarrollo de las fuerzas productivas (Marx), diseñan

40. Simmel, G., Filosofía del dinero, Madrid: Centro de Estudios Políticos, 1977, p. 354.

41. Ibídem, p. 591.

42. Eliade, M., El mito del eterno retorno, Madrid: Alianza, 1991, p. 104 s. 
un nuevo esquema de la esperanza humana en un mundo sin contradicciones. La historia gestiona la marea de hechos heteróclitos reorientándolos hacia una forma mundana de paraiso. Como recuerda Reinhardt Koselleck, «el perfectus religioso fue desbancado o sustituido por un progressus mundano. La determinación de fines de una posible perfección, que antiguamente sólo podía alcanzarse en el más allá, sirvió desde entonces para mejorar la existencia terrenal, lo que permitió sobrepasar la doctrina de las postrimerías arriesgándose a un futuro abierto. Finalmente, el objetivo de la perfección fue temporalizado, sobre todo por Leibniz, e introducido en la ejecución del acontecer mundano: progressus est infinitum perfectionis» ${ }^{43}$.

En este decorado, los acontecimientos pierden valor por sí mismos y se suceden como elementos necesarios de una unidad mayor que a su través espera consumarse. Constituyen momentos de un proceso que madura con su despliegue. La metáfora biologicista que inspira al marco de representaciones de la época cobra especial protagonismo. El movimiento de la historia sigue un sentido natural e irrevocable basado en un concepto de tiempo exento de novedad. O, dicho de otra forma, apoyado en una concepción continuista del devenir cronológico. En este sentido, Walter Benjamin habla del tiempo homogéneo y vacio de la modernidad en el que «los minutos cubren al hombre como copos» ${ }^{44}$ sin aportar contenido alguno que no se encuentre en el guión preestablecido. De suerte que, como dice Castoriadis, este concepto de tiempo «no es otra cosa que una relación de orden» ${ }^{45}$ en la que se desactiva el potencial semántico de los hechos en aras del cumplimiento del proceso escatológico al que deben su existencia y al que sirven. La acción humana pierde su valor intrínseco y se somete funcionalmente a un sentido exterior a la misma.

Se trata de un tiempo identitario en el que la historia se concibe como una identidad desplegada en el devenir cronológico. En él todo es previsible y predecible. Sirve como principio de identificación y organización de la vida social en el que se suceden ordenadamente los acontecimientos. El tiempo del trabajo en la fábrica, las fases del desarrollo técnico, los períodos sacros y profanos de la vida social necesitan de este concepto de tiempo en el que la complejidad de la sociedad moderna y la ausencia de garante metafísico convierte a la realidad en algo a gestionar técnicamente. En este sentido, como dice Castoriadis, «la institución explícita del tiempo en el capitalismo, en tanto que tiempo identitario o tiempo de referencia, es la de un flujo mensurable, homogéneo, uniforme, totalmente aritmético; y en tanto tiempo imaginario o tiempo de significación, el tiempo capitalista típico es un tiempo "infinito" representado como progreso indefinido, de crecimiento ilimitado, de acumulación, de racionalización, de conquista de la naturaleza, de aproximación cada vez mayor

43. Koselleck, R., Futures Past, Massachusetts: The MIT Press, Massachusetts Institute of Technology, 1985, p. 278.

44. Benjamin, W., Poesía y capitalismo, Madrid: Taurus, 1987, p. 72.

45. Castoriadis, C., op. cit. II, 1989, p. 37. 
a un saber exacto total, de realización de un fantasma de omnipotencia» ${ }^{46}$. La esperada dicha definitiva de una humanidad liberada insta a la acción social a la repetición, a la reincidencia, a evitar innovaciones que, al cabo, pudieran desviar a la historia de su curso predeterminado. La esterilidad de un tiempo en el que no incuba la novedad prepara la hegemonía de los medios (Estado, dinero, técnica) que dirigen una acción que se anticipa al futuro. La carga de contingencia del tiempo es contrarrestada por el predominio del plan, del método y del cálculo que participan de la confianza que, en tanto que mecanismo reductor de la complejidad, «emerge gradualmente en las expectativas de continuidad, que se forman como principios firmes con los que podemos conducir nuestras vidas cotidianas» ${ }^{47}$.

La figura del Estado también ocupa un papel relevante en la sociedad moderna. Es la institución política por definición. Su surgimiento echa raíces en el imaginario de la época en el que la autoconfianza del hombre moderno en su saber y en su pericia técnica pretende hacer transparente y maleable el espacio para el poder administrador. De hecho, como recuerda Bauman, el mayor problema que enfrenta el Estado no es el de la defensa de su territorio ante otros estados, sino el del regreso de la ambivalencia, una de cuyas expresiones es el extranjero cuya presencia pone en peligro la presunta naturaleza de sus límites y sus fronteras.

Hegel concibe el Estado como el momento político en el que se realiza la autoconciencia del Espíritu. En este sentido, la humanidad, ya depurada de mitos, supersticiones y automatismos, se tiene a sí misma como el agente que se autorregula el comportamiento desde el imperio de la ley como garante del orden social. Sólo desde la regulación normativa entienden la convivencia aquéllos que deciden libremente integrarse en esta comunidad política en la que ponen a buen recaudo la protección de sus vidas y sus propiedades. El Estado representa la institución señera de una sociedad, la moderna, que se soñó como civilización integrada por individuos despojados de cualquier atisbo de primitivismo en sus acciones transidas, por ello, de la racionalidad que deriva de la ley y del derecho.

El Estado promueve el orden sobre un espacio territorial en el que se impone atribuyéndose el monopolio legítimo de la violencia (M. Weber) y la regulación de la vida económica (T. Hobbes). Según Norbert Elias, el Estado es el órgano central que coordina las distintas unidades (sistemas) en que se diferencia la modernidad. Para ello arrebata a los individuos aislados la libre disposición sobre los medios militares, y lo mismo sucede con la facultad de cobrar impuestos sobre la propiedad o sobre los ingresos de los individuos. De esta manera, «los medios financieros que afluyen así a este poder central sostienen el monopolio de la violencia; y el monopolio de la violencia sostiene el monopolio fiscal. Ambos son simultáneos; el monopolio financiero no es previo al

46. Ibídem, p. 75 .

47. Luhmann, N., Confianza, Barcelona: Anthropos, 1996, p. 41. Las cursivas son mías. 
militar y el militar no es previo al financiero, sino que se trata de las dos caras de la misma organización monopolista» ${ }^{48}$.

Ya Hobbes subraya que el Estado debe organizar el tráfico económico protegiendo la propiedad de cada ciudadano, porque los grandes males de la sociedad humana proceden de las incontrolables tendencias de los hombres a apropiarse, a cualquier precio, lo que no poseen. Partiendo de la idea de que sólo donde hay ley existe el delito, el Estado debe organizar las condiciones de la actividad económica (en lo referido a los tipos de contrato de venta, trueque, préstamos, arrendamientos) y acuñar la moneda que circula legalmente dentro de su territorio.

La facultad protectora del Estado pasa necesariamente por la recaudación de dinero que constituye "su facultad nutritiva» ${ }^{49}$. Los impuestos con que se carga al conjunto de la sociedad estarían orientados al pago de los servidores públicos que se encargan de defender a los súbditos que han cedido su (mayor o menor) poder a Leviatán. En este sentido, la circulación del dinero conforma "el riego sanguíneo del Estado» ${ }^{50}$, ya que, en sintonía con Elias, hace posible el ejercicio del poder garantizando la convivencia pacífica de la sociedad.

Un análisis riguroso de la modernidad no puede pasar por alto la importancia de la ciudad como el escenario prototípico de las interacciones sociales transidas de una orientación económica ${ }^{51}$. Se trata de un lugar artificial, anónimo y levantado sobre el infinito natural, donde lo que define a la interacción humana es la universalidad abstracta del dinero monetario, y al individuo, su trabajo, su profesión, su saber hacer, su capacidad en detrimento de condiciones predadas como son las familiares, las confesionales, las de género. Su existencia responde a la necesidad de aislar un espacio social dedicado a la producción de la riqueza en el que se entroniza la racionalidad formal, el cálculo y el dinero. Desaparece de su horizonte toda referencia a lo local, lo simbólico o lo cultural convirtiéndose en un espacio sin identidad, sin rostro, por el que circula el dinero desentendiéndose de toda razón que no sea la estrictamente utilitarista. Así, Adam Smith habla de los comerciantes en términos de apátridas, en el sentido de que su radio de acción sobrepasa las fronteras de la nación bajo la idea de un universalismo que recuerda al propiamente cristiano pero con un tono claramente secular ${ }^{52}$. Simmel afirma que el dinero encuentra en la ciudad el escenario adecuado a su tránsito, toda vez que en él se concentra la industria, los bancos, el comercio, el mercado, la bolsa, es decir, instituciones de una cultura moderna que se reconoce en el gesto productivista.

El mismo diseño de la ciudad incipientemente moderna es estrictamente funcional. Por ello, como recuerda Bauman, es necesario delimitar y aislar las

48. Elias, N., El proceso de la civilización, México: FCE, 1989, p. 345.

49. Hobbes, T., Leviatán, Madrid: Alianza, 2000, p. 280.

50. Ibídem, p. 221.

51. Weber, M., La ciudad, Madrid: La Piqueta, 1987, p. 5.

52. Rosenvallon, P., Le capitalisme utopique, París: Éditions du Seuil, 1999, p. 94. 
funciones de trabajo, vida de hogar, esparcimiento, culto y administración. Cada función necesita su propio lugar, de igual modo que cada lugar debe servir a una única función. La propia concepción urbanística de la modernidad (personificada en la figura de Le Corbusier) incide en la aplicabilidad de la lógica cartesiana que separa y distingue lugares y funciones con nitidez. Estos intentos de homogeneizar el espacio urbano golpean en el corazón de los agentes individuales, privándoles de expresividad afectiva y lanzándolas al anonimato, al abandono y a la soledad.

En el recinto urbano, donde el individuo forja su identidad, se suspende todo atisbo de concesión expresiva (cultural, religiosa, artística), por los intercambios económicos en ella predominantes, y reina la cultura objetiva ${ }^{53}$ en la que lo cuantitativo homologa las cualidades, las funciones maniatan la iniciativa personal, la sobreestimulación semiológica desconcierta al individuo y la división del trabajo y la diferenciación funcional hacen imposible una visión unitaria de la realidad. Bajo esta atmósfera impersonal impregnada de abstracciones como precios, cálculos, el tiempo cronológico, etc., aumentan el número de encuentros económicos que manifiestan las múltiples dependencias entre los individuos. Se trata de interacciones fugaces, esporádicas e inconstantes en las que, al no dejar poso y surco entre las personas, se oscurece el cuerpo de la sociedad. En ellas rige la indiferencia en relación con las personas y la libertad de intercambio con ellas, ya que si, por un lado, el individuo es más dependiente de la totalidad social, por otro, es mucho más independiente respecto de elementos concretos de la misma.

El hombre de la gran ciudad, en palabras de Simmel, «precisa un número infinito de proveedores, trabajadores y colaboradores, sin los cuales estaría desamparado, pero que sólo tiene una vinculación absolutamente objetiva con ellos a través del dinero, de modo tal que no depende de una persona concreta, sino de la prestación objetiva, valorada en dinero, que pueden realizar cualesquiera personalidades fácilmente intercambiables" " 54 . En la ciudad circulan cantidades de dinero, mercancías y funciones, en definitiva, objetividad que acalla la expresividad individual. A diferencia de esto, en los intercambios rituales de las sociedades tradicionales, como ha recordado Jean Baudrillard ${ }^{55}$, circulan identidades simbólicas que se afirman ante el otro del que esperan reconocimiento y aprobación. En ellos se escenifica el gesto arquetípico en el que se simboliza la autorrepresentación del grupo. Las sociedades tradicionales intercambian expresándose, en la ciudad moderna el intercambio oculta las identidades desdibujándolas.

Sin lugar a dudas, el dinero hace las veces de masilla simbólica que unifica y comunica las diferentes partes (funciones) de este modelo de sociedad moderna. En un contexto en el que el lazo social prende al calor del proceso de inter-

53. Simmel, G., op. cit., 1977, p. 573.

54. Ibídem, p. 360.

55. Consultar sus trabajos El intercambio simbólico y la muerte, Caracas: Monte Ávila, 1980; Economía política del signo, México: Siglo XXI, 1990. 
cambio económico debido a la simpatía (en expresión de A. Smith) que, colateralmente, deriva del mismo, el dinero comparece como un elemento inexcusable sin el cual la equiparabilidad y la homologación de las mercancías serían imposibles. En el dinero típicamente moderno se adivina su trazo funcional y utilitarista. Es el medio por excelencia ${ }^{56}$, el medio sin más ${ }^{57}$. Con su uso la modernidad pretende reducir la complejidad de una estructura funcionalmente diferenciada en la que los intercambios económicos proliferan hasta el punto de poner en peligro otros modelos de intercambio social (Habermas). Precisamente su universalización obliga a inventar un medio generalizado de cambio anónimo e impersonal que circula al margen de límites y fronteras culturales y sociales.

El dinero viene a responder a la necesidad de facilitar lo máximo posible la realización de interacciones económicas a lo largo del mundo. Su hegemonía brota de un humus cultural que privilegia la intelectualización de la vida moderna en la que los conceptos y los signos gobiernan un modo de acción descolorido, previsible y calculador. Es un medio que habilita estructuras de comprensión cuantitativa que eliminan las imprecisiones y los equívocos adheridos a todo lenguaje humano. Huérfana de la seguridad de antaño, esta época identifica el pensamiento (calculatorio) con la realidad, de modo que ésta parece cursar mimetizando la secuencia ordenada y previsible del cálculo económico a instancias del dinero. En la modernidad, su presencia presupone un (modelo de) hombre apasionado por la riqueza económica y necesitado de un eje funcional que facilite su orientación en el tiempo bajo la formas de plan y previsión. En este sentido, ansía simplicidad en sus interacciones. Cosa que no ocurría en las sociedades tradicionales, cuando, bajo las formas premonetarias de dinero como el cerdo, la concha, la sal, el buey, etc., las equivalencias eran imposibles, ya que si alguien que «deseaba comprar sal, por ejemplo, pero sólo poseía ganado para dar a cambio de ella, debía comprar sal por el valor de todo un buey o toda una oveja a la vez. En pocas ocasiones podía comprar menos, porque aquello que iba a dar a cambio en pocas ocasiones podía ser dividida sin pérdida; y si deseaba comprar más, se habría visto forzado, por las mismas razones, a comprar el doble o el triple de esa cantidad, es decir, el valor de dos o tres bueyes, de dos o tres ovejas $^{58}$ ".

En esta situación, el torbellino de la actividad económica necesita formas de dinero fraccionadas que permitan intercambios por cualquier cantidad. Esa función la realiza la moneda acuñada por el Estado y de curso legal únicamente en el interior de sus fronteras. En cualquier caso, la moneda siempre representa una cantidad de riqueza, es decir, de oro ideal e imaginado, como sabía Marx ${ }^{59}$, que le hace equivalente a la misma cantidad de oro ideal e imaginado

56. Simmel, G., op. cit., 1977, p. 236.

57. Luhmann, N., Die Gesellschaft der Gesellschaft, Francfort del Meno: Suhrkamp, p. 723.

58. Smith, A., op. cit., 1997, p. 57.

59. MARX, K., El capital, vol. I, México: Siglo XXI, 1984, p. 117. 
que se represente en una moneda distinta acuñada por otro estado. El sistema del patrón-oro llega hasta principios del siglo $\mathrm{XX}^{60}$ facilitando un sistema de pagos internacionales que descansa en el oro como símbolo de la riqueza y de la estabilidad en la vida individual y social que glosa como pocos Stefan Zweig en su libro El mundo de ayer ${ }^{61}$. En este sentido, la imperiosa necesidad del dinero monetario queda confirmado por Luhmann cuando éste afirma que «en el sistema económico de la sociedad moderna, la autorreferencia paralela se realiza mediante un uso comunicador del dinero. La cuantificación del dinero lo hace libremente divisible — no infinitamente divisible - respecto de la adaptación a cada necesidad de división. De este modo, el dinero se puede usar universalmente, sin considerar lo compacto de los bienes económicos. Puede expresar cualquier operación económica, sobre todo en el caso de objetos indivisibles para los cuales sería difícil, por otro lado, encontrar una contraparte para el trueque. El dinero es el dividuum por excelencia que se puede adaptar a cualquier individualidad ${ }^{62}$. Como contrapartida, la enorme divisibilidad del dinero explica que nada (cosa) ni nadie (hombre) escape a una estimación puramente económica, no en vano «no hay en principio ningún límite a la cuantificación de la actividad humana» ${ }^{63}$.

En la vida moderna las formas de dinero se separan del referente áureo. Como bien sabe Foucault, re-presentan oro, pero no son oro. Las monedas de cobre, por ejemplo, o el papel moneda, están por el oro sin serlo, sin poseer su riqueza ancestralmente valorada. Ésta y su representación ya no se tocan, ni se rozan, por ello, las palabras y las cosas se separan. Los significados dejan de estar incorporados e impregnados en las cosas y empiezan a fraguarse por oposición (ya no por analogía, como en el símbolo) en el interior de un código. El dinero se desimboliza desvelando su rostro puramente funcional. Conviene recordar que en las sociedades tradicionales encontramos como ofrendas bienes que comparecen en el intercambio como dinero. No son ofrendas porque sean dinero, sino que en tanto que ofrendas se convierten en dinero o, al menos, sus atributos sacros favorecen su empleo como tal.

60. Tortella, G., La revolución del siglo XX, Madrid: Taurus, 2000, p. 135.

61. En este libro el autor se acerca al dinero como gran mito de una sociedad, la moderna, que descubre en la inmutabilidad de su soporte material, el oro, el asiento sólido que confiere seguridad a la vida de sus miembros. Afirma el autor que «nuestro dinero, la corona austríaca, circulaba en forma de resplandecientes monedas de oro y aseguraba así su inmutabilidad. Cada persona sabía cuánto poseía o cuánto le correspondía, lo que le era permitido y lo que le estaba prohibido. Todo tenía su norma, su peso y su medida determinados. [...] Esta sensación de seguridad era el bien más digno de ambicionarse para millones de hombres [...] La vida sólo era considerada digna de vivirse si estaba basada en esta seguridad, y círculos cada vez más amplios reclamaban su parte de aquel tesoro. Al principio sólo los pudientes disfrutaban de esta ventaja, pero pronto se adueñaron de ella grandes masas» (El mundo de ayer, México: Porrúa, 1983, p. 1-2).

62. Luhmann, N., Sistemas sociales, México: Universidad Iberoamericana/Alianza Editorial, 1991, p. 457.

63. TURnER, B.S., "Simmel, Rationalisation and the Sociology of Money», The Sociological Review, vol. 34, n. ${ }^{\circ} 1$, febrero, 1986, p. 99. 
Las formas monetarias de dinero con los soportes del cobre o del papel moneda (en especial éste último) sorprenden con su aparición a una sociedad, la incipientemente moderna, que no acierta a ver en esas formas (símbolos de) riqueza alguna. Todo lo contrario, carecen de aura, numen, valor intrínseco. Como afirma Marc Shell en su excelente libro Dinero, lenguaje y sociedad, la modernidad se enfrenta en este caso al problema de la credibilidad de los nuevos símbolos económicos desactivados semánticamente. Lo que está en juego es el problema de la simbolización en general, toda vez que «el papel moneda carece de una relación necesaria con su referente» ${ }^{64}$. De esta manera, el simbolismo religioso que auspició las primeras formas de dinero queda oscurecido por la eclosión de lo económico como forma de vida que impone una moral, una forma de vida, un lenguaje semiológico. La omnipresencia del dinero como medio de orientación de la acción (Weber) en un horizonte secularizado que convierte el beneficio económico en panacea a todos los males de la sociedad, explica la necesidad del individuo moderno de emplear vehículos lingüísticos que suministren precisión y simplicidad a sus expresiones.

El lenguaje simbólico se torna signo, es decir, formas cuantitativas, estadísticas, matemáticas, que designan, señalan y discriminan sin connaturalidad alguna (semejanza, analogía, similitud) entre el significante y el significado. Mientras el símbolo requiere de esta connaturalidad, como exponen sus estudiosos más relevantes ${ }^{65}$, de modo que en las sociedades tradicionales el dinero procedente del ritual no es sino la figura totémica (el cerdo, la concha, el buey, el oro) que evocalencarna la figura de lo divino en el que se reconocen sus miembros, en la sociedad moderna las formas semiológicas carecen de contenidos semánticos pues sólo contienen informaciones precisas que pretenden discriminar. El lenguaje se despoja de su encarnadura simbólica para devenir medio de expresión, signo que de-signa unilateralmente (algo del mundo). En afirmación de Bell al respecto de la pérdida de aura de la modernidad, excesivamente marcada por el imperio de la racionalidad teleológica, «las imágenes han desaparecido, las palabras han desaparecido y lo que queda —aparte de la elegancia, pero aun aquí se trata de la elegancia del ingenio formal- son fórmulas abstractas» ${ }^{66}$. La materia se despoja de significado y se mecaniza al servicio del diseño racional del mundo. Por ello, el papel dinero en el que su substrato material carece de la riqueza simbólica de formas de dinero prece-

64. SHell, M., Dinero, lenguaje y sociedad, México: FCE, 1990, p. 44.

65. Para el estudio del simbolismo en la acción humana, consultar: DURAND, G., Las estructuras antropológicas de lo imaginario, Madrid: Taurus, 1981; JUNG, C.G., Símbolos de transformación, Barcelona: Paidós, 1990; Arquetipos e inconsciente colectivo, Barcelona: Paidós, 1991; Neumann, E., Ursprungsgeschichte des Bewusstseins, Francfort del Meno: Fischer, 1981; ORTIZ-OsÉs, A., Las claves simbólicas de nuestra cultura, Barcelona: Anthropos, 1993; Metafisica del sentido, Bilbao: Universidad de Deusto, 1989; Visiones del mundo, Bilbao: Universidad de Deusto, 1995; Lanceros, Patxi y Ortiz-Osés, A., Diccionario de Hermenéutica, Bilbao: Universidad de Deusto, 1997.

66. BELL, D., Las contradicciones culturales del capitalismo, Madrid: Alianza Universidad, 1989, p. 102 . 
dentes en la historia, deja en evidencia la génesis estética del valor (económico) en la modernidad, toda vez que responde a «conexiones accidentales entre signo y referente, entre palabras y significados» ${ }^{67}$.

Cuando en la segunda parte del Fausto el emperador se encuentra ante el problema de oficializar en formas legales de dinero la riqueza áurea enterrada en las entrañas de la tierra, Mefistófeles le recuerda que «en los cimientos de los muros se encuentra oro acuñado y sin acuñar. ¿Y quién los saca a la luz? me preguntaréis: el poder de la naturaleza y el espíritu de un hombre capaz» ${ }^{68}$. Si en las sociedades tradicionales las formas de dinero se fraguaban «en los rituales sagrados que jugaban un papel destacado en la creación de la prosperidad ${ }^{69}$, en las sociedades modernas, el nuevo dios, el dios mundano, el hombre, se encarga de instituirlas desde la autoridad política, el Estado, que las regula. La escisión entre las palabras y las cosas explica el hecho de que en la economía moderna, "ningún objeto sea dinero per se»" ${ }^{70}$. Su condición de mero medio abre el abanico de posibilidades a un sinfín de objetos que, por su utilidad, se pueden convertir en tal independientemente de que signifiquen o no.

\section{La nueva religión civil: el mercado}

El componente imaginario que discrimina favorablemente el mercado como forma de interacción reguladora de la relación entre los individuos y las culturas y generadora de prosperidad y progreso de la humanidad se hace comprensible desde aquellas formulaciones teóricas que subrayan el intercambio como sustancia de lo social. En este caso, dos ejemplos destacados, como Adam Smith y Georg Simmel, inciden en que no hay sociedad al margen de los intercambios y las interacciones. La sociedad no es una realidad acabada que regula desde fuera la vida humana, sino que son sus prácticas las que dan pie a esquemas previsibles de acción que cristalizan en norma y orden.

Adam Smith recuerda que la división del trabajo, típicamente moderna, adquiere su auténtico significado desde la tendencia innata en el hombre a trocar, intercambiar y comerciar. Este rasgo forma parte de su naturaleza. En palabras de Smith, "esta división del trabajo, de la que derivan tantos beneficios, no es el efecto de ninguna sabiduría humana, que prevea y procure la riqueza general que dicha división ocasiona. Es la consecuencia necesaria, aunque muy lenta y gradual, de una cierta propensión de la naturaleza humana, que no persigue tan vastos beneficios; es la propensión a trocar, permutar y cambiar una cosa por otra ${ }^{71}$. Esta idea relativa a la tendencia humana al negocio y al trato

67. Shell, M., op., cit., 1990, p. 44.

68. Goethe, J.W., op. cit., 1991, p. 250.

69. Crawford,T., The Secret of Money, Nueva York: Putnam Book, 1994, p. 27.

70. PolanyI, K., "The Semantics of Money Uses», en Symbolic Anthropology (Dolgin, J.I.; Kemnitzer, D.S.; Schneider, D.M., eds.), Nueva York: Columbia University Press, 1977, p. 394 .

71. Smith, A., op. cit., 1997, p. 44. Las cursivas son mías. 
económico convierte en sustancial al intercambio y en adjetivo a la división del trabajo. Ésta se despliega a partir de la espontaneidad social relativa a los pactos y acuerdos económicos entre los hombres orientados al solo beneficio económico. Como recuerda $\mathrm{H}$. Arendt, los productores individuales orientan sus productos al ente anónimo llamado «mercado». Éste se autorregula al margen de la sociedad y de sus necesidades materiales estableciendo pautas de consumo con las que se da salida al ingente número de mercancías que invaden las metrópolis modernas y con las que se libra la batalla por el prestigio social. Como recuerda Lewis Mumford, la búsqueda de beneficio está en la base del desarrollo técnico, de la división del trabajo, de la moda, del consumo suntuario, etc.

Además, como efecto colateral, el lazo social se gesta al albor de los procesos de intercambio sin preexistir a éstos. El cuerpo de la sociedad se forja desde el encuentro de las unidades individuales que se requieren mutuamente para obtener beneficio con los excedentes de su trabajo. De suerte que en el comercio consubstancial al hombre se atisba el interés económico como dinamizador de las estructuras sociales y como principio de cristalización de redes de moralidad y solidaridad en las que se expresa la confianza y el reconocimiento recíproco entre los individuos que tratan en el mercado. Se deduce, por tanto, que Smith pretende ofrecer un modelo de sociedad antes que un modelo económico, de modo que «es la sociedad de mercado la que precede a la economía de mercado y no a la inversa» ${ }^{72}$.

Por otra parte, las aportaciones sociológicas de Georg Simmel inciden en este aspecto. Sus pautas teóricas suministran un modelo de constitución de lo social y, por lo mismo, una mirada impresionista ${ }^{73}$ con la que explicar la sociedad. Propone un acercamiento sociológico no basado en generalidades, leyes o constantes ahistóricas. Recuerda que los elementos estáticos que definen el orden social a cada momento obedecen a la interacción continuada de los agentes. Su repetición y reincidencia devienen norma y ley, acaban obligando y regulando su comportamiento. Por ello Simmel insta al sociólogo a hacer una genealogía de las formas que atiendan al tempo (lento) de maduración en el que la interacción se solidifica en institución. Hacer sociología es, básicamente, rastrear los momentos que preceden a y posibilitan la cristalización de la relación. Lejos de limitarse a describir el producto acabado con el que orientamos la acción, el sociólogo debe detenerse en el aquí y ahora del encuentro del que brota el lazo social. Se trata de redescubrir la sociedad «en status nascens, claro es que no en su origen primero, históricamente inasequible, sino en aquél que trae consigo cada día y cada hora. Constantemente se anuda, se desata y se torna a anudar la socialización entre los hombres, en un ir y venir continuo, que encadena a los individuos, aunque no llegue a formar organizaciones propiamente dichas. Se trata aquí de los procesos microscópicos-moleculares que se ofrecen

73. FrISBY, D., Sociological Impressionism, Londres: Routledge, 1981. 
en el material humano; pero que constituyen el verdadero acontecer, que después se organiza o hipostasia en aquellas unidades y sistemas firmes, macroscópicos ${ }^{74}$. En el caso de la modernidad, el intercambio hegemónico es el económico al que las unidades individuales se acercan desde el presupuesto de su irreductibilidad a lo social. La antítesis individuo-sociedad florece en la modernidad porque el culto al individuo, del que habla Durkheim, convierte en prioritario al beneficio económico de las partes individuales sobre la buena salud del orden social que, al fin y a la postre, es una derivación de aquél. Sin embargo, aunque la preponderancia de los agentes individuales oscurece el cemento común e invisible de la sociedad moderna, es ésta la que se sueña bajo la forma de individuo propietario de su vida y sus bienes que se impone ineluctablemente como el destino del hombre moderno.

Puede decirse de las sociedades modernas que se aferran al mito del comercio como mecanismo de integración de unos individuos de cuya acción (y sólo de ésta) brota el lazo social sin depender de instancias exteriores a ellos. El eje de este modelo lo constituye una idea del hombre universal, representado en cada individuo y en cada cultura, que se enseñorea de su primitivismo de antaño interactuando con los otros desde la autocontención, el temple y la mesura. No oculta el sustrato pasional que desata sus actos, el fondo emocional que tira de él. Sin embargo, su mayoría de edad viene dada por una idea de sociedad que se piensa desde los individuos autónomos que aspiran al interés económico, pero no a cualquier precio. Aquí radica el componente civilizador y educador de la pasión comercial. El elemento regulador de su conducta no le viene dado por imposiciones exteriores (la Iglesia o por pacto con un soberano político como se recoge en el Leviatán de Hobbes), sino por la simpatía de la que habla A. Smith, es decir, por la mutua comprensión y aprobación que los hombres realizan de los motivos de los otros hombres que, llevados inicialmente por el interés económico, sintonizan, más allá de éste, en una misma pasión, dando curso a actos que cristalizan en estructuras de moralidad en las que se reconocen recíprocamente. Por ello, lejos de derivar en una sociedad en permanente estado de guerra, la pasión (comercial) puede dar pábulo a una sociedad civilizada (A. Smith), a «una versión más amable que la del Leviatán de Hobbes» ${ }^{75}$. En concreto, tras el mercado se adivina en el hombre moderno «la aspiración a encontrar un medio de desdramatizar el cara a cara de los individuos, de desapasionar sus relaciones, de desactivar la violencia virtual de las relaciones de fuerza. El mercado pretende responder a estas exigencias. Intenta construir el poder de una mano invisible, neutra por naturaleza en tanto no personalizada» 76 .

La sociedad de los individuos (N. Elias) basada en el mercado se concibe como autoinstituida ${ }^{77}$ desde el momento en que la actividad mercantil libre-

74. Simmel, G., Sociología I, Madrid: Alianza Universidad, 1986, p. 29.

75. DodD, N., The Sociology of Money, Cambridge (Ingl.): Polity Press, 1994, p. 119.

76. Rosenvallon, P., op. cit., 1999, V.

77. Ibídem, p. 11. 
mente gestionada por los individuos genera, colateralmente, el cemento invisible que les vincula moralmente más allá de su interés económico inicial. Siendo éste el acicate de sus encuentros, su efecto salutífero desemboca en redes de solidaridad que regulan el tráfico social. El orden social es prolongación y cristalización (no deliberada) de la interacción. En este sentido, los pensadores liberales que reflexionaron sobre el mercado coincidiendo con el advenimiento de la modernidad no se acercan a él desde el prisma del individuo depredador que no encuentra término a su sed de dinero. Antes bien, ven en él un principio político que, en cuanto tal, se pretende como «el arte de combinar pasiones. Su objetivo es el de armonizar las pasiones de tal forma que la sociedad pueda funcionar. La aritmética de las pasiones se convierte, a partir del siglo XVII, en el modo de suministrar un fundamento sólido al ideal del bien común del pensamiento escolástico. No en vano, las pasiones son el material sobre el que trabajan los políticos» ${ }^{78}$. Esta tesis es la que subraya Albert Hirschman en Las pasiones y los intereses, al recordar, en relación con las pasiones, que, imposibles de contener exteriormente vía poder político, o interiormente vía concienciación religiosa, la modernidad libera de entre ellas la pasión económica orientada al interés en la medida en que obliga a la neutralización recíproca de las unidades individuales que se acercan al mercado. Es más, su virtualidad descansa en que en ella se combinan armoniosamente las pasiones y la razón: a pesar de la sed de enriquecimiento económico, éste exige pulir y refinar el gesto humano, sublimando y depurando de irracionalidad sus modos de interacción con el otro.

Se constata, por tanto, que al hablar de mercado plasmado en el encuentro azaroso de los individuos, el trasfondo al que apunta es el orden de la sociedad. De hecho, una de sus figuras destacadas, Adam Smith, "piensa la economía como fundamento de la sociedad y el mercado como catalizador del orden social» ${ }^{79}$. De este modo, el mercado se convierte en auténtica "religión civil» ${ }^{80}$ en la que, azarosamente, se armonizan lo público y lo privado. Una de las razones que pueden ayudar a explicar esta armonización descansa en la idea de la simpatía que defiende A. Smith a la hora de explicitar las virtualidades de la interacción mercantil. Según el fundador de la ciencia económica, la simpatía "puede hoy utilizarse sin mucha equivocación para denotar nuestra compañía en el sentimiento ante cualquier pasión» ${ }^{81}$. Si bien el mercado atrae a los individuos entre sí, en él brotan estructuras normativas derivadas de las afinidades anímicas de los individuos. La simpatía alude al efecto no deseado en el que se positiviza la competitividad económica a partir del surgimiento de pautas de interacción que, basadas en unas pasiones comunes, facilitan el reconocimiento recíproco de sus miembros. La contribución socializadora de la simpatía obedece a la necesidad de todo hombre de compartir sus sentimien-

78. Ibídem, p. 14 .

79. Ibídem, p. 70 .

80. Haesler, A.J., Sociologie de l'argent et posmodernité, Ginebra: Libraire Droz, 1995, p. 291.

81. SMith, A., La teoría de los sentimientos morales, Madrid: Alianza, 1997, p. 52. 
tos con los demás, de ser reconocido por el otro en el fondo de su ser. En palabras de Adam Smith, "cualquiera que sea la causa de la simpatía, cualquiera que sea la manera en que sea generada, nada nos agrada más que comprobar que otras personas sienten las mismas emociones que laten en nuestro corazón y nada nos disgusta más que observar lo contrario» ${ }^{82}$. Además, el juego de reconocimientos recíprocos exige a los individuos salir de sí, desdoblarse y trabar contacto con ese espectador imparcial (del que habla A. Smith), ese Otro generalizado (al que remite G.H. Mead), que permite valorar los motivos de los actos del otro y de uno mismo, ajustar los comportamientos a lo que, en cada caso, se espera de uno y reconocer, en el extremo, que el individuo piensa y enjuicia desde y por la sociedad.

En el escenario de esta sociedad civil mercantil la interacción económica no se despliega a partir de relaciones de dependencia entre los individuos que ponen en situación de necesidad a unos respecto a otros. Sobre tales desniveles es imposible edificar un modelo de sociedad exento de violencia y desigualdad. El mercado carece de los nexos sociales premodernos basados en el parentesco y el clientelismo. Se alza sobre la idea de simpatía natural que remite a un «mecanismo procesual sin contenidos emocionales o morales intrínsecos. La gente modera su comportamiento para atraer la simpatía de los otros continuando la interacción si los otros "simpatizan" con su idea y su conducta»"

La simpatía no apunta a un contenido concreto que, a priori, pudiera comprometer a los individuos. Los compromisos, de darse, siempre resultan de la acción, en este caso, del reconocimiento que los individuos efectúan del quehacer del otro y de los motivos subyacentes. Si el encuentro humano es inicialmente comercial, la simpatía hace que algo común crezca entre los individuos, que, celosos de sus propios intereses económicos, se van viendo comprometidos en e identificados con entramados nómicos derivados de su propia intervención social. La aprobación recíproca entre hombres que deciden libremente sus actos desemboca en horizontes de acción compartidos que apuntan a ley, hábito, norma, es decir, a nexos de moralidad en su hacer común que se inician en la búsqueda del interés económico. La simpatía, por tanto, «establece la base moral de la sociedad comercial en la asociación de individuos privados que se plasma en un espacio social no construido por constreñimientos institucionales. El control mutuo de la conducta que resulta a partir de un juego complejo de interacciones y mecanismos reflexivos, es la fuente y el prototipo de la conducta moral. Por ello, la simpatía modera ideas y comportamientos, robusteciendo los sentimientos de comprensión mutua en un espíritu esencialmente democrático. Con ello se disuelven los lazos exclusivistas definidos por la costumbre, el grupo corporativo, la posición y el estado» ${ }^{84}$.

82. Ibídem, p. 57.

83. Silver, A., «Friendship in Commercial Society: Eighteenth-Century Social Theory and Modern Sociology", American Journal of Sociology, 95, 1990, p. 1482.

84. Ibídem, p. 1484. 
Los efectos fecundos de la simpatía, que prenden en los encuentros sociales en el mercado, también obedecen a que la pasión económica no es en absoluto tan voluble y efímera como el resto de las pasiones. La Ilustración escocesa la promueve porque el amor hacia el dinero conlleva necesariamente constancia y sistematicidad en la conducta. O lo que es lo mismo, la repetición de encuentros entre los (mismos) agentes movidos inicialmente por una fidelidad absoluta al apetito económico genera las condiciones sociales para el conocimiento mutuo, la complicidad, la confianza recíproca, en definitiva, la simpatía. Y es que la pasión económica implica reiteración y constancia, más aún, tiempo, plan y sistema para consumarse. El enriquecimiento vía cálculo (que es lo que distingue al capitalismo moderno de cualquier versión de capitalismo precedente en la historia según Weber) obliga al individuo a introducir elementos de enorme previsibilidad en su comportamiento. Por tanto, la simpatía labra su obra en el intercambio mercantil, ya que, por oposición a otras pasiones, el interés económico se convierte en el principio rector de una acción basada en la repetición y la reincidencia, no sujeta a modificaciones espontáneas y súbitas. La obtención del interés es cosa de tiempo, esto es, exige constancia y denuedo, método y plan. Ignora, por tanto, la improvisación, la sorpresa y lo repentino. En este sentido, la pasión económica acaba provocando pautas de interacción entre agentes que se re-conocen en su pasión compartida, duradera y constante y que se sirven de ellas para establecer un mutuo conocimiento, así como redes de solidaridad, cooperación y confianza. Por tanto, «existe una ventaja para los demás en esta persecución individual del interés, puesto que su actuación se hace consecuentemente transparente y predecible, casi tanto como la de una persona totalmente virtuosa» ${ }^{85}$. Norbert Elias afirma, en referencia al potencial pacificador de las coacciones económicas, que «son menos efectivas, más moderadas, más estables y menos repentinas que las coacciones que ejercen unos sobre otros los hombres en una sociedad de guerreros sin monopolio. Estas coacciones, incorporadas al conjunto de las posibilidades que se abren a los individuos en la sociedad, obligan a una actitud previsora y reflexiva del pasado, más allá del momento presente y en correspondencia con las secuencias más largas y diferenciadas en que se imbrica ahora de modo automático toda acción. Exigen del individuo un dominio permanente de sus movimientos afectivos e instintivos momentáneos a causa de la necesidad de tomar en consideración las consecuencias más lejanas de sus acciones» ${ }^{86}$.

\section{La hora del dinero}

El medio dinero brilla con luz propia en la aurora de la modernidad. A los ojos del nuevo (modelo de) hombre emancipado, su concurso contribuye a la 
domesticación definitiva de la irracionalidad y al triunfo de la civilización. Según Norbert Elias, el dinero encarna la autocontención pasional del hombre moderno, que, forzado a actuar desde el cálculo, aleja la violencia y la fuerza de su comportamiento. Por ello, «además de ser la prefiguración del mal — como concibe aún la tradición cristiana- el dinero es un mal necesario, un receptáculo que canaliza las pasiones destructivas de las relaciones humanas» ${ }^{87}$. En él cuajan buena parte de las esperanzas de una sociedad que parece distanciarse de la barbarie de antaño a partir de una idea de mercado universal que fuerza a los individuos y a las culturas a interactuar gestionando las pasiones y las emociones. El suelo firme de la nueva sociedad lo constituye, por tanto, el interés individual que provoca encuentros entre los hombres despojados de sus impurezas pulsionales y de sus hábitos heredados. Como sostiene Sigmund Freud, la cultura derrota a la naturaleza y el orden a la ambivalencia. La violencia entre los hombres queda desterrada. De hecho, la competitividad, que se da con especial énfasis en la economía moderna, sería, según Veblen, una versión canalizada y depurada emocionalmente de las luchas y combates crueles y encarnizados que eran moneda común en períodos anteriores de la historia. En este contexto, el dinero supone «la victoria de la escasez sobre la fuerza» ${ }^{88}$.

En efecto, como bien sabe Luhmann, en un modelo social aglutinado por una economía abierta al interés económico, la escasez se traduce en escasez de dinero, la penuria material, en penuria de dinero. Quien carece de él no puede operar en el mercado, limitándose a observar cómo actúan los demás. Por el contrario, aquél que lo posee tiene libertad de movimientos y posibilidad de elegir. En todo caso, su presencia tiende a civilizar las pasiones. Con él, la estructura de suma cero del mecanismo tradicional de cambio se transforma en un juego de suma positiva. De modo que bajo la forma dinero la riqueza no perece, deviene, no se agota, circula socializándose. Dicho de otro modo, el dinero hace posible, en su circulación permanente, que el pago y el no-pago se simultaneen en una misma operación económica. A esto se refiere Luhmann cuando habla del doble círculo inherente a la actividad económica, es decir, "producción de la capacidad de pago para el receptor y producción de la incapacidad de pago para el que paga ${ }^{89}$. El dinero no se diluye en la operación económica, tan sólo cambia de manos, de modo que la posibilidad de beneficio en el juego de los intercambios se abre para cualquier miembro de la sociedad.

El derecho a la prosperidad individual se democratiza con ayuda del dinero. Es precisamente la idea de un futuro mejor lo que contiene el estallido de la fuerza y de la violencia humana en la sociedad moderna. La nueva imagen del hombre burgués próspero y reconocido socialmente se democratiza y parece encontrarse al alcance de cualquier miembro de la sociedad. Las pasiones se contienen porque el dinero neutraliza los efectos disgregadores inherentes

87. Haesler, J.A., op. cit., 1995, p. 215. Las cursivas son mías.

88. Luhmann, N., Die Wirtschaft der Gesellschaft, Francfort del Meno: Suhrkamp, 1989, p. 253.

89. Lummann, N., Ökologische Kommunikation, Opladen: Westdeutscher, 1995, p. 56. 
a la escasez, es decir, abre la puerta a un juego de suma positivo. Como recuerda Simmel, en el intercambio no-monetario de las sociedad tradicionales sólo una de las partes estaba interesada en despojarse de un objeto o en obtenerlo. En los intercambios mercantiles son las dos partes las interesadas, ya que ambas se benefician, una satisfaciendo una necesidad, otra acaparando riqueza económica, es decir, dinero.

Las sociedades tradicionales portadoras de intercambios basados en juegos de suma cero disponían de condiciones favorables para el saqueo, la guerra, el pillaje, el robo, toda vez que la idea de prosperidad era imperceptible. Las posiciones parecían inmutables en un modelo social estático. Sin embargo, en la modernidad «la sociedad entera queda así referida a un tiempo cuyos vínculos con el pasado se debilitan y difuminan, hasta hacer verosímil el nuevo ideal político burgués y republicano: la igualdad. Ya no es el pasado lo que configura a los agentes sociales, sino que éstos vienen a serlo más bien por el futuro, por el cúmulo de posibilidades que se abren como resultado de comunicación entre iguales. La identidad ya no es el producto de una genealogía, sino el lugar desde donde se avista el horizonte de lo biográfico. Si la historia es lo necesario constituido desde la contingencia, no es respecto de esa necesidad donde los hombres resultan ser iguales, sino respecto de lo posible y futuro: los hombres son iguales porque son libres y a la inversa. Para esta nueva humanidad la historia se ha abierto por delante, al tiempo que se cerraba y denostaba por detrás; la historia se llama futuro y a su ritmo propio se puede llamar progreso y prosperidad ${ }^{90}$. Y en este horizonte social, el dinero representa la novedosa noción de posibilidad como ninguna otra institución, noción que invita a la paciencia, la estrategia y la esperanza. Frente a las viejas formas de sociedad en las que la distinción era monopolio de una minoría selecta (el sacerdote, el héroe, el rey, el noble), su circulación permanente abre expectativas de enriquecimiento y de notoriedad social a todos los individuos. Sólo así puede contemplarse el componente racionalizador y civilizador de su curso social. Esta idea la corrobora Alexis de Tocqueville cuando, tras su viaje a la próspera Norteamérica (1831), donde el dinamismo económico deriva de la igualdad de oportunidades para todos los individuos, afirma que allí no existe "un ciudadano pobre que no eche una mirada de esperanza y de envidia hacia los goces de los ricos, y cuya imaginación no se apodere anticipadamente de los bienes que la suerte se obstina en rehusarle» ${ }^{91}$.

Sin embargo, como bien recuerda Hans Joas ${ }^{92}$, el ideal de una sociedad pacificada y civilizada no se ha realizado. Acontecimientos de una violencia extrema han tenido lugar en la historia reciente de la humanidad. Lo más cruel y salvaje del hombre ha brotado con una virulencia inusitada. Además de otras muchas razones de naturaleza histórica, política y religiosa, la economía tam-

90. Marín, H., op. cit., 1997, p. 210.

91. TocQueville, A. de, La democracia en América, México: FCE, 1987, p. 490. Las cursivas son mías.

92. JOAS, H., «Die Modernität des Krieges», Leviathan, 24 Jahrgang, Heft 1, 1996, p. 13-24. 
bién tiene su responsabilidad al difundir universalmente «la promesa de riqueza absoluta, el sueño del individuo de disponer de la totalidad de posibilidades humanas, que es inherente a la forma de poder del dinero» ${ }^{93}$. Este sueño, lejos de favorecer la armonía entre los individuos y las culturas, la ha debilitado porque la ambición humana que se esconde en el dinero no tiene límites. Con su circulación se difunden ideales y esperanzas de individuos anónimos que no encuentran límite a sus expectativas de triunfo, que no cejan en el empeño de lograr la distinción como un universal antropológico que bajo formas como el deseo mimético propuesto por René Girard ${ }^{94}$, el consumo ostentoso estudiado por Thorstein Veblen ${ }^{55}$, la moda de la que habla Georg Simmel ${ }^{96}$ y el habitus de clase explicitado por Pierre Bourdieu ${ }^{97}$ ha tematizado la ciencia social de nuestra época. De este modo, el poder del dinero se ha revelado como altamente nocivo en el marco de un mito social que alienta la acción encaminada a la prosperidad. Encarna una pasión (económica) que acaba privatizando las conciencias, separando y enfrentando a los hombres y oscureciendo el orden normativo de una sociedad que ha debilitado el espacio público. Por ello, hoy más que nunca es necesario el retorno crítico de la propia sociedad a los supuestos imaginarios que han hecho de ella un proyecto social truncado. Sólo rememorando la condición social, histórica y contingente de toda mitificación humana puede reconducirse un curso de acción social abocado a la catástrofe. En resumen, llega la hora de «despertar del sueño dogmático, del narcotizante de la riqueza absoluta» ${ }^{98}$.

93. Deutschmann, Ch., Die Verheissung des absoluten Reichtums, Francfort del Meno: Campus Verlag, 1999, p. 179.

94. GiRARD, R., El chivo expiatorio, Barcelona: Anagrama, 1986.

95. Veblen, T., op. cit., 1974.

96. Simmel, G., Cultura femenina y otros ensayos, Barcelona: Alba Editorial, 1999.

97. Bourdieu, P., La distinción, Madrid: Taurus, 1991.

98. Deutschmann, Ch., op. cit., 1999, p. 172. 